\title{
The Role of Sharia Monetary Instrument in Liquidity Management and Performance Improvement of Islamic Banking Financial in Indonesia
}

\author{
Mohd Rizal Muwazir, Deky Anwar \& Ab Mumin Ab Ghani
}

\begin{abstract}
The Role of Sharia Monetary Instrument in Liquidity Management and Performance Improvement of Islamic Banking Financial in Indonesia. This study analyzes the variables of liquidity and financial performance of Islamic banks that affect the number of transactions in Islamic monetary instruments. The aim is to find out which instruments is better in supporting liquidity management and financial performance of Islamic banks in Indonesia. This study uses the CAR and FDR variables as proxies of liquidity and ROA as a proxy for the financial performance of Islamic banks. While the proxy for sharia monetary instruments in Indonesia is the variable SBIS and SBPUS. This study uses monthly Islamic banking reports in Indonesia for the period January 2015 to September 2017. Data is processed and analyzed by Augmented Dickey-Fuller (ADF) Stationery Test as a way of testing stationary data and then testing hypotheses using Vector Autoregression (VAR). This study found that the the most contributing variable to the changes in transaction volume in Islamic monetary instruments was the variable liquidity, namely CAR and FDR. In Addition, SBIS sharia monetary instruments are better used by Islamic banking in Indonesia compared to SBPUS.
\end{abstract}

Keywords: monetary liquidity instrument, Islamic banking performance, financial, Indonesia

\begin{abstract}
Abstrak: Peranan Instrumen Moneter Syariab dalam Perbaikan Menejemen Likuiditas dan Penampilan Finansial Perbankan Islam di Indonesia. Penelitian ini menganalisis variabel likuiditas dan kinerja keuangan bank syariah yang mempengaruhi jumlah transaksi pada instrumen moneter syariah. Tujuannya untuk mengetahui instrumen mana yang lebih baik dalam mendukung manajemen likuiditas dan kinerja keuangan bank syariah di Indonesia. Penelitian ini menggunakan variabel CAR dan FDR sebagai proksi dari likuiditas dan ROA sebagai proksi untuk kinerja keuangan bank syariah. Sedangkan proksi untuk instrumen moneter syariah di Indonesia variabelnya adalah SBIS dan SBPUS. Penelitian ini menggunakan laporan bulanan perbankan syariah di Indonesia periode Januari 2015 hingga September 2017. Data diolah dan dianalisis oleh Augmented Dickey-Fuller (ADF) Stationery Test sebagai cara pengujian data stasioner dan kemudian pengujian hipotesis menggunakan Vector Autoregression (VAR). Studi ini menemukan bahwa variabel yang paling berkontribusi terhadap perubahan volume transaksi pada instrumen moneter syariah adalah variabel likuiditas yaitu CAR dan FDR. Selain dari pada itu, instrumen moneter syariah SBIS lebih baik digunakan oleh perbankan syariah di Indonesia dibandingkan dengan SBPUS.
\end{abstract}

Kata Kunci: Instrumen likuiditas moneter, kinerja perbankan syariah, keuangan, Indonesia

Senior Lecturer Department of Shariah and Management Academy of Islamic Studies University of Malaya, UIN Raden Fatah Palembang \& Assoc. Prof. Department of Shariah and Management Academy of Islamic Studies University of Malaya, Malaysia

E-mail:mrmkl@um.edu.my, dekyanwar_uin@radenfatah.ac.id,abmumin@um.edu.my 


\section{Introduction}

The rapid development of sharia banking in Indonesia requires the availability of monetary instruments in accordance with the operational mechanisms and principles of sharia banking. ${ }^{1}$ It aims to solve the problems faced by sharia banking in Indonesia that happens along with its growth, especially liquidity problem. ${ }^{2}$ However, the development and availability of monetary instruments in accordance with sharia also raises a new problem. ${ }^{3}$ There is the tendency of Islamic banking in Indonesia to place funds in sharia monetary instruments in a relatively large number and frequency. ${ }^{4}$ There is also the dilemma of choosing the placement of funds in sharia monetary instruments which is better for liquidity management and financial performance of sharia banking. ${ }^{5}$

To create a healthy and steady banking system, Bank Indonesia issues various forms of monetary policy. ${ }^{6}$ As a means to implement this policy, Bank Indonesia uses various monetary instruments such as open market operations with SBI facilities, discount rate, reserve requirement, and moral suasion. All of these monetary instruments have their respective functions, one of which is for the effectiveness of liquidity management in creating banking stability. For sharia banking, Bank Indonesia provides monetary instruments in accordance with Islamic sharia principles called Certificates of Bank Indonesia Syariah (SBIS) as

${ }^{1}$ Ahmad Azam Sulaiman Mohamad, Mohammad Taqiuddin Mohamad, and Muhamad Lukman Samsudin, 'How Islamic Banks of Malaysia Managing Liquidity? An Emphasis on Confronting Economic Cycles', International Journal of Business and Social Science, 4, no. 7 (2013), p. 253-63.

${ }^{2}$ Simon Archer, Rifaat Ahmed Abdel Karim, and Venkataraman Sundararajan, 'Supervisory, Regulatory, and Capital Adequacy Implications of Profit-Sharing Investment Accounts in Islamic Finance', Journal of Islamic Accounting and Business Research, 1, no. 1 (2010), p. 10-31.

${ }^{3}$ Tariqullah Khan and Habib Ahmed, Risk Management: An Analysis of Issues in Islamic Financial Industry (Occasional Papers), Occasional Papers (The Islamic Research and Teaching Institute (IRTI), 2001), p. 59-77 <https://ideas.repec.org/p/ris/irtiop/0091.html>.

${ }^{4}$ Rajesh K. Aggarwal and Tarik Yousef, 'Islamic Banks and Investment Financing', Journal of Money, Credit and Banking, 32, no. 1 (2000), p. 93-120<https://doi.org/10.2307/2601094>.

5 Anwar D, Dampak Transaksi Instrumen Moneter Syariah Terhadap Kinerja Perbankan Syariah di Indonesia (Jakarta: (Master Thesis) Universitas Indonesia, 2007).

${ }^{6}$ Enrico Tanuwidjaja and Keen Meng Choy, 'Central Bank Credibility and Monetary Policy in Indonesia', Journal of Policy Modeling, 28, no. 9 (2006), p. 1011-22 <https://doi. org/10.1016/j.jpolmod.2006.05.003>. 
well as other instruments such as reserve requirement and moral suasion. Sharia monetary instrument serves as a place to put excess funds (over liquidity) of sharia banking, so idle funds that exist in Islamic banking can still be channeled optimally. In addition to SBIS, other sharia monetary instruments are Value Latter of Islamic Money Market (SBEFA) as means of placement and fulfillment of sharia bank liquidity. ${ }^{7}$

Banking, in general, will manage liquidity in various ways for the purpose of getting the most out of the funds collected. Deep and Schaefer's (2004) research shows that when banks experience excess liquidity, there will be a transformation of bank liquidity caused by various variables such as loans, credit risks, and deposits. ${ }^{8}$ Transformation of this liquidity will be directed to the money market, where improvement of banking liquidity in normal condition has no effect on banking stability. However, the total increase in bank liquidity will reduce banking stability. Increased liquidity would also increase non-performing financing. ${ }^{9}$ Likewise with interbank lending transactions similar banks that engage in interbank lending transactions will create stability in the banking system. Meanwhile the opposite applies to banks that are not similar in which interbank lending transactions will create instability for the banking system that results directly or indirectly. ${ }^{10}$

The existence of sharia monetary instrument and its relation with the performance of sharia banking in Indonesia has been found since 2000 . There have been plenty of research related to both of these variables. Pramuharjo (2005) conducted research on the influence of monetary policy on the performance of sharia banking. This research uses monetary

7 'Perilaku Bank dalam Penghimpunan dan Penempatan dana: Implikasi Terhadap Likuiditas - Bank Sentral Republik Indonesia' <https://www.bi.go.id/id/publikasi/wp/Pages/Perilaku-bankDalam-Penghimpunan-dan-Penempatan-Dana.aspx>.

${ }^{8}$ Akash Deep and Guido K. Schaefer, 'Are Banks Liquidity Transformers?', 2004.

9 Wolf Wagner, 'The Liquidity of Bank Assets and Banking Stability', Journal of Banking \& Finance, 31, no. 1 (2007), p. 121-39 <https://doi.org/10.1016/j.jbankfin.2005.07.019>. Douglas W. Diamond, 'Liquidity, Banks, and Markets', Journal of Political Economy, 105, no. 5 (1997), p. 928-56 <https://doi.org/10.1086/262099>.

${ }^{10}$ Giulia Iori, Saqib Jafarey, and Francisco G. Padilla, 'Systemic Risk on the Interbank Market', Journal of Economic Behavior \& Organization, 61, no. 4 (2006), p. 525-42<https:// doi.org/10.1016/j.jebo.2004.07.018>. 
instruments such as SBI, and macroeconomic variables such as inflation, real GDP, and market share of sharia banks to conventional banks as independent variables while the dependent variable is the performance of sharia banking, the amount of deposits, the level of liquidity and Islamic banking financing. The results of this study indicate that the SBI interest rate has a negative effect on deposits, liquidity, and Islamic banking financing, while the market share of sharia banks against conventional banks is positively related. ${ }^{11}$ More specific research on sharia monetary instruments and their impact on the performance of sharia banking in Indonesia was done by Kurniasih (2005). This research used financing variable and PUAS as variable influencing SWBI. The results of this study showed that there was a positive and strong influence between financing with SWBI while there was a negative effect between PUAS and SWBI. ${ }^{12}$ Irsadunas's research (2004) discussed various factors that encouraged sharia banks to place their funds in SWBI and PUAS, which resulted in FDR factor and 1 -month interest rate of SBI. ${ }^{13}$ Thantawi (2005) also conducted research on factors that determine the volume of SWBI and PUAS transactions, which resulted in the percentage of bonus and reward ratio product-sharing to be obtained. ${ }^{14}$

Lori. et al. (2004) from Kings College Strand London University did research on the systemic risks posed by interbank loans. This study aimed to see the impact of interbank lending on banking stability. The study was conducted on 400 banks by dividing into two types of banks i.e similar banks and non- similar bank. The variables studied were the rate of return on investment, interest on inter-bank lending, the interest rate on the deposit and the reserve requirement. The model used in this study was a model of mathematical and statistical calculations built on

${ }^{11}$ A. B. Pramuharjo, Analisis Pengaruh Kebijakan Moneter Terhadap Deposito, Pembiayaan, dan Likuiditas Perbankan Syariah di Indonesia' (Jakarta: Univeritas Indonesia, 2005).

${ }^{12}$ Afiati Kurniasih, Pengaruh Pembiayaan dan Transaksi Pasar Uang Antar Bank Syariah Terhadap Sertifikat Wadiah Bank Indonesia Tahun 2000-2004, 2005.

13 Irsadunas Irsadunas, 'Analisis Terhadap Faktor-Faktor Yang Mempengaruhi Posisi Outstanding SWBI.' (unpublished Thesis, Universitas Indonesia, 2004).

${ }^{14}$ Rifqy Thantawi, Pengaruh Kebijakan Bonus SWBI dan Penjaminan Pemerintah Terhadap Tingkat Imbalan Pasar Uang Antarbank Berdasarkan Prinsip Syariah di Indonesia (Pasca Sarjana UI, Tesis, 2005). 
the theory described in the study. The results of this study indicated that when similar banks conducted interbank loan transactions, it would create stability of the banking system. Meanwhile the opposite applies to banks that were not similar in which interbank lending transactions would create instability for the banking system that may result directly or indirectly. ${ }^{15}$ Deep and Schaefer (2004) conducted a study to see if the large and medium-sized commercial banks existed in the United States did the liquidity transformation. The results showed that there was liquidity transformation in commercial banks in the United States even with small transformation rates. The more influential variables on liquidity transformation were credit risk and loan. ${ }^{16}$

Wagner (2005) conducted a study with the aim to find out whether increasing the liquidity condition of banking assets would reduce banking stability. The results showed that the increased liquidity of banking assets in normal condition would not have an effect on banking stability. However, the total increase in bank liquidity would reduce banking stability. Increased liquidity of banking assets would also increase nonperforming loans. ${ }^{17}$ Alshatti (2015) conducted research on the influence of liquidity management on the profit of Jordanian commercial banks conducted between the period of 2005 and 2012. The results showed that quick ratio and investment ratio positively affected the available funds, while the liquidity ratio and current asset ratio negatively affected the profitability of the commercial banks in Jordan. These early researchers recommended that there is a need to optimize the use of available liquidity in the various aspects of the investment to improve the profitability of banks. ${ }^{18}$ Lartey (2015) conducted research on the relationships of liquidity and profits of the banks listed on the Ghana stock exchange. The findings indicated that for the period 2005-2010, both liquidity

${ }^{15}$ Giulia Iori, Saqib Jafarey, and Francisco G. Padilla, 'Systemic Risk on the Interbank Market', p. 1-28.

${ }^{16}$ Akash Deep and Guido K. Schaefer, 'Are Banks Liquidity Transformers?', p. 1-53.

${ }_{17}$ Wolf Wagner, 'The Liquidity of Bank Assets and Banking Stability', p. 1-24.

${ }^{18}$ Ali Sulieman Alshatti, 'The Effect of the Liquidity Management on Profitability in the Jordanian Commercial Banks', International Journal of Business and Management, 10, no .1 (2014), p. 62. 
and bank profits decreased. It was also found that there was a very weak positive relationship between liquidity and profit of registered banks in Ghana. ${ }^{19}$ Sandy (2015) conducted a study on the influence of liquidity and solvency of Indonesian banks financial performance listed on the Indonesia Stock Exchange period 2010-2012. The results of this study indicated that the NPL did not affect the ROA while LDR, CAR, and DER simultaneously affected the ROA. ${ }^{20}$

From these various research, we can conclude that there is a strong relationship between conventional and sharia monetary instruments with the performance of sharia banking. In the context of sharia monetary instruments and sharia banking, the relationship between variables can be explained. The amount of transaction and frequency that occurs in sharia monetary instrument both directly and indirectly will affect the sharia banking performance. On the contrary, the high level of liquidity and improvement financial performance in sharia banking will result in sharia banking to consider sharia monetary instrument as a means to cover the operational cost and payment of profit sharing ratio of the third party as well as to anticipate future risks.

This study complements several previous studies, Diamond (1996), Deep (2004), Wagner (2005), and Lori, et.al (2004) only explained that banks will transform when there are liquidity problems, while Irsadunas (2004), Pramuharjo (2005), Kurniasih (2005), Thantawi (2005), Alshatti (2015), Lartey (2015), and Sandy (2015), found that there was an influence between liquidity and banking performance. While this study determines which Islamic monetary instruments are better used by Islamic banking in managing their liquidity. Based on the introduction above, there are several research problems: (1) What are the variables in liquidity management and sharia financial performance which contributes to the change of transaction volume in sharia monetary instrument?

${ }^{19}$ Victor Curtis Lartey, Samuel Antwi, and Eric Kofi Boadi, 'The Relationship between Liquidity and Profitability of Listed Banks in Ghana', International Journal of Business and Social Science, 4, no. 3 (2013).

${ }^{20}$ Gyan Exqyu Sandy, 'Pengaruh Liquiditas dan Solvabilitas Terhadap Kinerja Keuangan Perbankan Indonesia Yang Terdaftar di Bursa Efek Indonesia Pada Tahun 2010 - 2012', 2015 $<$ http://repository.unej.ac.id/handle/123456789/64431>. 
(2) Which sharia monetary instrument is better to be chosen by sharia banking in liquidity management and financial performance of sharia banking in Indonesia? Based on the problems above the purposes of this study are: (1) To find out which variables are present in liquidity management and sharia financial performance which contributes in the change of transaction volume in sharia monetary instrument. (2) To decide on which sharia monetary instrument is better to be chosen by sharia banking in liquidity management and financial performance of sharia banking in Indonesia.

\section{Literature Review Sharia Banks in Indonesia}

The Bank is a financial intermediary institution generally established with the authority to accept deposits of money, lend money, and issue promissory notes or banknotes. A bank is a business institution that collects funds from the public in the form of savings and distributes them to the community in the form of credit, or other forms in order to increase the standard of living for people. ${ }^{21}$ In Indonesia, banking services have spread to rural areas. Financial institutions in the form of banks in Indonesia are Commercial Banks, Rural Banks (BPR), Sharia Commercial Banks, and also BPR Sharia (BPRS). ${ }^{22}$ From time to time the condition of the banking world in Indonesia has undergone many changes. Besides the internal development of the banking world, the change cannot be separated from the influence of developments outside the banking world, such as the real sector in the economy, politics, law, and social. ${ }^{23}$ The same also happens with the development of sharia banking. The rapid development of sharia banking is inseparable from

${ }^{21}$ Thorsten Beck, Ross Levine, and Norman Loayza, 'Finance and the Sources of Growth', Journal of Financial Economics, Special Issue on International Corporate Governance, 58, no. 1 (2000), p. 261-300 <https://doi.org/10.1016/S0304-405X(00)00072-6>.

${ }^{22}$ Te-Kuang Chou and Agung Dharmawan Buchdadi, 'Bank Performance and Its Underlying Factors: A Study of Rural Banks in Indonesia', Accounting and Finance Research, 5, no. 3 (2016), p. 55 <https://doi.org/10.5430/afr.v5n3p55>.

${ }^{23}$ Rahmatina Kasri, The Determinants of Islamic Banking Growth in Indonesia (Rochester, NY: Social Science Research Network, 1 December 2010) <https://papers.ssrn.com/abstract=1740500>. 
the effectiveness of basic and operation concepts of the sharia bank itself. Operational performance of sharia banking is a fundamental factor in measuring, analyzing, and evaluating the progress of sharia banking. ${ }^{24}$

In its implementation, the operational performance of sharia banking is indicated from various ratio such as; profitability, total asset, NonPerforming Financing (NPF), total third party fund, distributed financing, Financing to Deposit Ratio (FDR), liquidity level and so forth. ${ }^{25}$ All of these variables become the concern of management team of sharia banking. The main business of banking is on how to keep all variables in desired conditions of the management team in accordance with the needs of each sharia bank. Therefore, managing all of these indicators professionally and seriously is a necessity The number of third-party funds and distributed financing is the core of sharia banking business objectives. In its operation, if the entire third-party funds can be distributed properly by sharia banking, then the opportunity to improve sharia banking performance is wide open. On the other hand, financing is also determined by the number of third-party funds that can be collected by sharia banking. This function is called the financial intermediary function. ${ }^{26}$ Sharia principles and operational performance are also measured by other indicators such as; placement of funds at Bank Indonesia in the form of Bank Indonesia Sharia Certificates (SBIS), interbank money market transactions based on sharia principles (SBPUS) as well as other services. ${ }^{27}$

In terms of collecting the third-party funds, sharia banking must take more effective steps. Sharia banking needs innovative and creative effort in providing savings and deposits products. Sharia banking not only should rely on its wadiah account, mudharabah savings deposits but also be able to make a new breakthrough in collecting funds from the

${ }^{24}$ Ari Kuncara Widagdo and Siti Rochmah Ika, 'The Interest Prohibition and Financial Performance of Islamic Banks: Indonesian Evidence', International Business Research, 1.3 (2009), 98.

${ }^{25}$ Pipit Afiatun and Sudarso Kaderi Wiryono, 'Efficiency and Productivity of Indonesian Islamic Banking', Journal of Technology Management, 9, no. 3 (2010).

${ }^{26}$ Anas Hidayat and Sobirin Malian, Lembaga-Lembaga Keuangan Umat Kontemporer (Yogyakarta: UII Press, 2002).

${ }^{27}$ Daud Vicary Abdullah, 'Liquidity Management in Institutions Offering Islamic Financial Services', 2010. 
people so that it becomes an attractive place to serve as a means of saving money. ${ }^{28}$ Similar to funds collecting products, funds distributing products in sharia banking should also be innovative with an uncomplicated procedure. If sharia banking is able to create innovations in its financing then the financing model offered by sharia banking to the public will be in demand. In addition to the innovation of financing products, sharia banking should also have a prudent financing management system because if it is not careful, there will be a huge chance of bad loans happening. ${ }^{29}$ Sharia banking should also consider the sector to be financed in distributing financing. This is important since the general purpose of Islamic economics is to create the welfare of the people as depicted in the Shariah Maqashid. ${ }^{30}$ It is inconceivable that sharia banking merely commercializes its main functions and roles, regardless of the public interest. Financing has a close relationship with this because financing is directly related to the real deposit. Shariah banking ideally should distribute its funding to sectors that can promote the welfare of society in general and facilitate lower and middle-class people to be able to access financing as capital to run their business. ${ }^{31}$

Various indicators of sharia banking performance above will determine its future prospect. All of these indicators must be controlled seriously by the management of sharia banking and also should become the concern of various institutions related to sharia banking, especially the Financial Services Authority (OJK). If the performance of sharia banking experiences a decrease then the trend of sharia banking will be developing slowly. On the other hand, a fine sharia banking performance will encourage the growth of other sharia financial institutions such as sharia insurance, sharia leasing, sharia capital market, as well as encourage

${ }^{28}$ Yuli Andriansyah, 'Kinerja Keuangan Perbankan Syariah di Indonesia dan Kontribusinya Bagi Pembangunan Nasional', La_Riba, 3, no. 2 (2009), p. 181-196.

${ }^{29}$ Muhammad Ramzan and Muhammad Imran Zafar, 'Liquidity Risk Management in Islamic Banks: A Study of Islamic Banks of Pakistan', Interdisciplinary Journal of Contemporary Research in Business, 5, no. 12 (2014), p. 199-215.

${ }^{30}$ Umer Chapra, Sistem Moneter Islam, di Terjemahkan Oleh Ikhwan Abidn Basri (Jakarta: Gema Insani Press dan Tazkia Cendekia, 2000).

${ }^{31}$ Hafas Furqani and Ratna Mulyany, 'Islamic Banking and Economic Growth: Empirical Evidence from Malaysia.', Journal of Economic Cooperation \& Development, 30, no. 2 (2009). 
the growth of companies that finance their business according to the Islamic principle. The development of these sharia economic institutions will facilitate the Moslems to be able to practice their religious teachings with more kaffah. ${ }^{32}$

\section{Sharia Banking Liquidity}

Liquidity management is part of a larger financial industry risk management framework, which is associated with all institution, both conventional ones and sharia since most bank failures are caused by the difficulty in managing their liquidity problems. Any commercial, conventional or sharia bank is required to continue to control and manage liquidity positions effectively and cautiously. ${ }^{33}$ According to Indonesian Big Dictionary, the definition of liquidity, in general, is the company's cash position and its ability to meet liabilities (debt) on time. When associated with banking institutions, it is defined as the bank's ability to pay off short-term debt at the time billed by clients or stakeholders at any time. Thus, liquidity is an ease of converting assets into cash from each bank concerned. Liquidity can also be defined as the ability to sell assets in a short time with minimal losses. ${ }^{34}$ Liquid assets are assets that are stored in cash or invested in instruments that can be converted into cash forms such as time deposits, deposits, and investments in short-term government liquid securities.

Bank liquidity is also recognized as a bank's ability to meet its obligations, particularly short-term funding obligations. ${ }^{35}$ From the asset point of view, liquidity is the ability to convert all assets into cash. In terms of liabilities, liquidity is the ability to meet funding needs

${ }^{32}$ Mulya Siregar, 'Agenda Pengembangan Perbankan Syariah Untuk Mendukung Sistem Ekonomi Yang Sehat di Indonesia: Evaluasi, Prospek dan Arah Kebijakan', Jurnal Iqtisad, 3, no. 1 (2002).

${ }^{33}$ Rifki Ismal, 'The Management of Liquidity Risk in Islamic Banks: The Case of Indonesia' (unpublished PhD Thesis, Durham University, 2010).

${ }^{34}$ Reyadh Nofan Said Al-Adwan, 'Risk Management in Islamic Banking', International Review of Management and Business Research, 3, no. 4 (2014), p. 1855.

${ }_{35}$ Noraini Mohd Ariffin, 'Liquidity Risk Management and Financial Performance in Malaysia: Empirical Evidence from Islamic Banks', Aceh International Journal of Social Science, 1, no. 2 (2012). 
through an increase in portfolio liabilities. ${ }^{36}$ The first purpose of liquidity management is to maintain the liquidity position of banks in positions determined by financial authorities such as Bank Indonesia and/or the Financial Services Authority. The second one is managing liquidity means to always meet all cash flow needs including unexpected requirements, such as a sudden withdrawal from current accounts or unpaid deposits, third to minimalized idle funds, and fourth to maintain the liquidity position and cash flow projection to always be in a safe position, especially in interest rate fluctuations. ${ }^{37}$

\section{Financial Performance of Sharia Banking}

Banking as part of the financial system of a country needs a good performance to create a healthy and strong banking system. Healthy and strong banking will provide confidence in economic growth and investment certainty. Banks will be able to maximize their role in the economy if the bank is healthy. If the bank is not healthy then: (1) the intermediation function is impaired, so allocation and provision of funds for financing the productive sector becomes limited, (2) the traffic of the banking system is not smooth, and (3) the effectiveness of monetary policy is disrupted. ${ }^{38}$ In order to ensure that banks perform prudential banking functions in running the banking business, Bank Indonesia (BI) establishes an assessment of the health status of banks with Bank Indonesia Regulation No: 13/1/PBI/2011 dated January 5, 2011, which regulates the Rating System of General Bank Health. Bank healthiness is the result of bank's assessment of bank risk and performance (Bank Indonesia Regulation No. 13/1/ PBI/2011). The Level of Health and financial performance of the bank is the ability to conduct normal banking operation and able to meet all of its obligations well in a consistent manner with applicable banking regulations. ${ }^{39}$

${ }^{36}$ Nurul Ichsan, 'Pengelolaan Likuiditas Bank Syariah', Al-Iqtishad: Jurnal Ilmu Ekonomi Syariah, 6, no. 1 (2014), p. 97-120.

${ }^{37}$ Boy Leon and Sony Ericson, Manj Aktiva Pasiva Bank Nondevisa (Jakarta: Grasindo, 2007).

${ }^{38}$ Chandra Utama, 'Mengukur Tingkat Kesehatan Bank di Indonesia', Bina Ekonomi, 10, no. 1 (2006).

${ }^{39}$ Titin Ruliana, Rina Masyitoh Hariyadi, and Siti Winarsih, 'Health Level of Bank Using 
Financial performance can be defined as a measure of corporate income and operations financially. ${ }^{40}$ In assessing the overall financial condition of a company, the income statement and balance sheet are the most important, since the income statement is a statement of the company's operating performance and the balance sheet report shows the company's net income. In Indonesia's sharia banking there are several financial ratios that must be reported to the Financial Services Authority of the Republic of Indonesia by all Sharia Banks, among which are:

Table 1. Sharia Banking Financial Reporting Ratios

\begin{tabular}{|c|c|c|}
\hline Ratio & Formula & Information \\
\hline $\begin{array}{l}\text { Minimum Capital } \\
\text { Adequacy Requirement } \\
\text { (KPMM). }\end{array}$ & $\begin{array}{l}\text { Capital. } \\
\text { Weighted assets in } \\
\text { accordance to credit, } \\
\text { operation, and } \\
\text { marketing risks. }\end{array}$ & $\begin{array}{l}\text { Calculation of Weighted } \\
\text { Equity and Risk Based Assets } \\
\text { shall be made in accordance } \\
\text { with the provisions } \\
\text { concerning the obligation of } \\
\text { minimum. capital provision } \\
\text { of Islamic banks. }\end{array}$ \\
\hline $\begin{array}{l}\text { Problematicproductive } \\
\text { assets and non- } \\
\text { productive assets to } \\
\text { total productive assets } \\
\text { and non-productive } \\
\text { assets. }\end{array}$ & $\begin{array}{l}\text { Productive assets } \\
\text { problematic }+ \\
\text { Non- productive } \\
\text { asset problematic } \\
\text { Total productive assets } \\
+ \text { total non-productive } \\
\text { assets. }\end{array}$ & $\begin{array}{l}\text { The scope of components } \\
\text { and quality of productive } \\
\text { assets and non-productive } \\
\text { assets in accordance with } \\
\text { the provisions on the quality } \\
\text { assessment of sharia banks } \\
\text { and sharia business units. }\end{array}$ \\
\hline $\begin{array}{l}\text { Problematic productive } \\
\text { assets to total of } \\
\text { productive assets. }\end{array}$ & $\begin{array}{l}\text { Problemative } \\
\text { productive } \\
\text { assets (excluding } \\
\text { administrative account } \\
\text { transactions). } \\
\text { Total of productive } \\
\text { assets (excluding } \\
\text { administrative } \\
\text { accounttransactions). }\end{array}$ & $\begin{array}{l}\text { The scope of components } \\
\text { and the quality of } \\
\text { productive assets in } \\
\text { accordance with the } \\
\text { provisions of the assessment } \\
\text { of asset quality of sharia } \\
\text { banks and sharia business } \\
\text { units. }\end{array}$ \\
\hline
\end{tabular}

Risk Based Bank Rating.', Scientific Papers: Management, Economic Engineering in Agriculture \& Rural Development, 16, no. 1 (2016).

${ }^{40}$ Mustafa Hassan Mohammad Adam, 'Evaluating the Financial Performance of Banks Using Financial Ratios-A Case Study of Erbil Bank for Investment and Finance', European Journal of Accounting Auditing and Finance Research, 2, no. 6 (2014), p. 162-177. 


\begin{tabular}{|c|c|c|}
\hline $\begin{array}{l}\text { Reserves of Impairment } \\
\text { Losses (CKPN) of } \\
\text { financial assets to } \\
\text { productive assets }\end{array}$ & $\begin{array}{l}\text { CKPN financial assets. } \\
\text { Total productive } \\
\text { assets (excluding } \\
\text { administrative } \\
\text { accounttransactions) }\end{array}$ & $\begin{array}{l}\text { CKPN is the Bank's } \\
\text { mandatory reserve in } \\
\text { accordance with the } \\
\text { Statement of Financial } \\
\text { Accounting Standards } \\
\text { (PSAK) on Financial } \\
\text { Instruments and Accounting } \\
\text { Guidelines for Indonesian } \\
\text { Sharia Banking (PAPSI), } \\
\text { which includes individual } \\
\text { CKPN and collective } \\
\text { CKPN. }\end{array}$ \\
\hline Gross NPF & $\begin{array}{l}\text { Financing problem } \\
\text { Amount of Financing }\end{array}$ & $\begin{array}{l}\text { - Financing is the } \\
\text { financing as stipulated } \\
\text { in the provisions on the } \\
\text { assessment of the quality } \\
\text { of sharia commercial } \\
\text { banks and sharia } \\
\text { business units. } \\
\text { Troubled financing is } \\
\text { poorly funded, hesitated, } \\
\text { and stuck. }\end{array}$ \\
\hline Net NPF & $\begin{array}{l}\text { Problematic } \\
\text { Financing - CKPN } \\
\text { Financing } \\
\text { Amount of Financing }\end{array}$ & $\begin{array}{l}\text { - Financing is the } \\
\text { financing as stipulated } \\
\text { in the provisions on the } \\
\text { assessment of the quality } \\
\text { of sharia commercial } \\
\text { banks and sharia } \\
\text { business units. } \\
\text { Troubled financing is } \\
\text { poorly funded, hesitated, } \\
\text { and stuck. }\end{array}$ \\
\hline Return on Asset (ROA) & $\begin{array}{l}\text { Profit before tax } \\
\text { Average total assets. }\end{array}$ & $\begin{array}{l}\text { Profit before tax is profit } \\
\text { before taxation of current } \\
\text { year. }\end{array}$ \\
\hline Return on Equity (ROE) & $\begin{array}{l}\text { Profit after tax. } \\
\text { Average equity. }\end{array}$ & $\begin{array}{l}\text { Profit after tax is net profit } \\
\text { for the year after tax. }\end{array}$ \\
\hline NI (Net Income) & $\begin{array}{l}\text { Financing revenues } \\
\text { after profit sharing } \\
\text { (rewards and bonuses). } \\
\text { Average total earning } \\
\text { assets. }\end{array}$ & $\begin{array}{l}\text { Revenue after profit sharing } \\
\text { - (reward and bonus) is the } \\
\text { income distribution of funds } \\
\text { after deducting income, } \\
\text { rewards and bonuses. }\end{array}$ \\
\hline
\end{tabular}




\begin{tabular}{|c|c|c|}
\hline $\begin{array}{l}\text { NOM (Net Operating } \\
\text { Margin) }\end{array}$ & $\begin{array}{l}\text { Funding revenues } \\
\text { after the sharing of } \\
\text { operating expenses. } \\
\text { Average earning assets. }\end{array}$ & $\begin{array}{l}\text { The revenue distribution } \\
\text { channel after profit sharing } \\
\text { is revenue disbursement } \\
\text { after deducting operating } \\
\text { income and operating } \\
\text { expenses (annualized). }\end{array}$ \\
\hline $\begin{array}{l}\text { Operating Expenses } \\
\text { for Operating Income } \\
\text { (BOPO) }\end{array}$ & $\begin{array}{l}\text { Total operating } \\
\text { expenses } \\
\text { Total operating } \\
\text { income. }\end{array}$ & $\begin{array}{l}\text { Operating expenses are } \\
\text { operating expenses including } \\
\text { profit and bonus sharing. }\end{array}$ \\
\hline $\begin{array}{l}\text { Financing of profit } \\
\text { sharing on total } \\
\text { financing }\end{array}$ & $\begin{array}{l}\text { Sharing Financing } \\
\text { Amount of financing }\end{array}$ & $\begin{array}{l}\text { Financing of profit sharing } \\
\text { is all financing with a profit } \\
\text { sharing contract that uses } \\
\text { both profit and loss sharing } \\
\text { and revenue sharing. }\end{array}$ \\
\hline $\begin{array}{l}\text { Financing to Deposit } \\
\text { Ratio (FDR) }\end{array}$ & $\begin{array}{l}\text { Financing } \\
\text { Third-party funds. }\end{array}$ & $\begin{array}{l}\text { Financing is the } \\
\text { financing as stipulated } \\
\text { in the provisions of the } \\
\text { bank's quality assessment } \\
\text { of shariah general bank } \\
\text { and sharia business unit. } \\
\text { Third party funds } \\
\text { include demand deposits, } \\
\text { savings deposits, and } \\
\text { deposits (excluding bank } \\
\text { re-transfers). }\end{array}$ \\
\hline
\end{tabular}

Source: Appendix to Letter of the Financial Services Authority Number 18 / SEOJK.03 / 2015

\section{Sharia Monetary Instrument}

So far, the monetary policy conducted by Bank Indonesia in the context controlling circulated money is done through the implementation of open market operations. In order for the implementation of open market operations based on sharia principles to run properly, it is necessary to create an instrument in accordance with the principles of sharia. ${ }^{41}$ The instrument is called Certificate of Bank Indonesia Syariah

${ }^{41}$ Awwal Sarker, 'An Evaluation of Islamic Monetary Policy Instruments Introduced in Some Selected OIC Member Countries', 2016. 
(SBIS). This instrument is a means of short-term funding especially for sharia banks that experience excess liquidity. ${ }^{42}$

Not only can sharia banking take advantage of its excess liquidity in SBSI, it can also have other instrument options such as Sharia Money Market Securities (SBPU Syariah) consisting of Sharia State Treasury Certificate, Mutual Investment Certificate of Mudharabah (SIMA) and other Sharia SBPU. In addition to SBPU Syariah, sharia banking can also fulfill other sharia instruments contained in the capital market called Islamic Capital Shariah Securities (SBPM Syariah) consisting of State Sharia Securities (SBSN), Mutual Funds and Sharia Certificates, SubSukuk Sukuk, and other Sharia SBPs. ${ }^{43}$

In this study the discussion of sharia monetary instruments only to the two sharia monetary instruments namely SBIS and SBPU Syariah without SBPM Syariah instruments. The utilization of sharia monetary instruments of SBIS and SBPU by sharia banking may depend on the form and amount of repayment set by Bank Indonesia. If bonus and profit sharing ratio of SBIS and SBPU is large then this will attract the attention of Islamic banking to put funds in SBIS or SBPUS, and will directly reduce the amount of fund disbursement to the financing and will also result to the revenue of sharia banking. However, looking in the context of the comparison between SBIS and SPUS, of course, the character of each sharia monetary instrument is highly determined. SBIS has a smaller risk when compared with SBPUS because it is directly managed by Bank Indonesia and it is credible. Also, Bank Indonesia is obliged to return the funds placed in the SBIS as a whole plus bonuses. Whereas SBPUS is based on mudharabah contract which is potentially risky. However, the placement of funds in SBPUS tends to give a bigger return than SBIS bonus. Therefore, the choice of placement of excess liquidity of sharia banks is very dependent on the policy used by sharia banks. If the sharia bank prefers the idle funds to be safe with little

${ }^{42}$ Rifki Ismal, 'Central Bank Islamic Monetary Instruments: A Theoretical Approach', Studies in Economics and Finance, 28, no. 1 (2011), p. 51-67.

${ }^{43} \mathrm{Al}$-Sayed O, Money Market Instruments in Conventional and Islamic Banks, 3 (European International Journal of Science and Humanities, 2015), P. I. 
return then it will place its funds on SBIS but if the bank is willing to take a bigger risk with a bigger return then it will choose to place its fund in SBPUS. However, the tendency of sharia bank fund placement in SBIS will be bigger because of the small risk. ${ }^{44}$

\section{Research Hypothesis}

Based on the questions and research objectives that have been discussed previously, the hypotheses in the study are as follows:

1. It can be proposed thatliquidity variables have a larger contribution in encouraging transactions on SBIS and SBPUS sharia monetary instruments.

2. It can be proposed that SBIS monetary instrument is better than SBPUSfor liquidity management and financial performance of Sharia Banking in Indonesia.

\section{Research Methodology}

\section{Research Design}

This research uses quantitative, descriptive, ratio and econometric analysis to determine the utilization of sharia monetary instrument for liquidity management and improvement of sharia banking performance in Indonesia in the 2015-2017 period from 13 types of sharia general bank (BUS) and 21 types of sharia business units (UUS) in Indonesia. The 13 BUS and 21 UUS are the totals of all types of Islamic banks in Indonesia except Sharia Rural Banks (BPRS). Taking data from the entire population of Islamic banks is intended so that the results of this study is more similar to the real character of Islamic banks in Indonesia.

The data obtained were processed by using the Vector Autoregression analysis tool (VAR) with E-Views 9 SV statistic program. The equations system in VAR does not depend too much on economic theory. The variables in VAR equation system can be selected as long as the relationship

44 Irsadunas Irsadunas, 'Analisis Terhadap Faktor-Faktor Yang Mempengaruhi Posisi Outstanding SWBI.' 
between variables is still relevant to the economic theory or can be explained logically. ${ }^{45}$ From the data and analysis tools used we were able to find variables in the management of liquidity and financial performance of Islamic banking which contribute to the change in the volume of transactions in Islamic monetary instrument as well as to determine which sharia monetary instrument is better for liquidity management and financial performance of sharia banking in Indonesia.

\section{Data Collection and Analysis}

The data used in this study are secondary data taken from the published report of sharia banking statistic by Financial Services Authority (OJK) RI 2015, 2016 and 2017. The data included outstanding SBIS and SBPUS transactions as a proxy from the sharia monetary instrument, CAR, and FDR data as a proxy from liquidity and ROA as a proxy from financial performance of sharia banking in Indonesia. This is the monthly data of sharia banking starting from January 2015 to September 2017 with 33 months in total. The data type is time series. The obtained data were analyzed by using an econometric approach of impulse response function (IRF) and variance decomposition (VD) in which both models were included in Vector Autoregression (VAR analysis). Before the testing IRF and VD stage, the data was tested first by using unit root test and deciding the lag optimum. If the result of unit root test is fine and the lag optimum has been obtained, then IRF and VD testing can be performed.

\section{Research Model}

This research used VAR equation model as described below:

1. SBIS $_{\mathrm{t}}={ }_{\beta 10}+\alpha_{11}\left(\mathrm{~L} \mathrm{CAR}_{\mathrm{t}}+\alpha_{12}\left(\mathrm{~L} \mathrm{FDR}_{\mathrm{t}}+\alpha_{13}\left(\mathrm{~L} \mathrm{ROA}_{\mathrm{t}}+\alpha_{14}(\mathrm{~L}) \mathrm{SBIS}_{\mathrm{t}}\right.\right.\right.$ $+\alpha_{15}(\mathrm{~L})$ SBPUS $_{\mathrm{t}}+\varepsilon_{1 \mathrm{t}}$

2. $\mathrm{CAR}_{\mathrm{t}}={ }_{\beta 10}+\alpha_{21}(\mathrm{~L}) \mathrm{CAR}_{\mathrm{t}}+\alpha_{22}(\mathrm{~L}) \mathrm{FDR}_{\mathrm{t}}+\alpha_{23}(\mathrm{~L}) \mathrm{ROA}_{\mathrm{t}}+\alpha_{24}(\mathrm{~L}) \mathrm{SBIS}_{\mathrm{t}}$ $+\alpha_{25}(\mathrm{~L})$ SBPUS $_{t}+\varepsilon_{2 \mathrm{t}}$

${ }^{45}$ Laksono B.G, Model Vector Auto Regressive (Depok: Universitas Indonesia., 2006). 
3. $\mathrm{FDR}_{\mathrm{t}}={ }_{\beta 10}+\alpha_{31}(\mathrm{~L}) \mathrm{CAR}_{\mathrm{t}}+\alpha_{32}\left(\mathrm{~L} \mathrm{FDR}_{\mathrm{t}}+\alpha_{33}(\mathrm{~L}) \mathrm{ROA}_{\mathrm{t}}+\alpha_{34}(\mathrm{~L}) \mathrm{SBIS}_{\mathrm{t}}\right.$ $+\alpha_{35}(\mathrm{~L})$ SBPUS $_{\mathrm{t}}+\varepsilon_{3 \mathrm{t}}$

4. $\mathrm{ROA}_{\mathrm{t}}={ }_{\beta 10}+\alpha_{41}(\mathrm{~L}) \mathrm{CAR}_{\mathrm{t}}+\alpha_{42}(\mathrm{~L}) \mathrm{FDR}_{\mathrm{t}}+\alpha_{43}(\mathrm{~L}) \mathrm{ROA}_{\mathrm{t}}+\alpha_{44}(\mathrm{~L}) \mathrm{SBIS}_{\mathrm{t}}$ $+\alpha_{45}(\mathrm{~L})$ SBPUS $_{\mathrm{t}}+\varepsilon_{4 \mathrm{t}}$

5. SBPUS $_{\mathrm{t}}={ }_{\beta 10}+\alpha_{51}\left(\mathrm{~L} \mathrm{CAR}_{\mathrm{t}}+\alpha_{52}\left(\mathrm{~L} \mathrm{FDR}_{\mathrm{t}}+\alpha_{53}(\mathrm{~L}) \mathrm{ROA}_{\mathrm{t}}+\alpha_{54}(\mathrm{~L}) \mathrm{SBIS}_{\mathrm{t}}\right.\right.$ $+\alpha_{55}(\mathrm{~L})$ SBPUS $_{t}+\varepsilon_{5 \mathrm{t}}$

\section{Definitions of Operational Variables}

a. Capital Adequacy Ratio(CAR): is the ratio used to calculate the capital adequacy to the total assets owned. The value of CAR is obtained by Capital / Total Assets formula.

b. Financing to Deposit Ratio (FDR): is the amount of ratio between the total third-party funds with distributed financing. The value of this ratio is obtained by Total Third-Party Funds/ Total Financing formula.

c. Return of Asset (ROA): is the income ratio if compared to the assets owned. This value is obtained by Nett Income / Total Assets.

d. Certificate of Sharia from Bank Indonesia (SBIS): is the total amount of funds placed on Sharia Banking in SBIS.

e. Sharia Money Market Securities (SBPUS): SBPUSis the total of transaction from money market sharia in Indonesia consisting of transaction on Sharia State Treasury Certificate, Mutual Investment Certificate of Mudharabah (SIMA) and other SBPU sharia.

\section{Findings and Interpretation}

\section{Statistic Analysis and Interpretation}

\section{a. Unit Root Test}

Unit root test is used to see whether the data is stationary or not. The analysis tool used to do the test is the Augmented Dickey-Fuller (ADF).

The table below presents the results of unit root test to variables included in research model on first difference level. 
Table 2. The Result of Unit Root Test

\begin{tabular}{cccc}
\hline Variables & ADF Statistics & P-Value & Order of Integration \\
\hline ROA & 7,2827 & 0,0000 & $1(0)$ \\
\hline CAR & 6,9818 & 0,0000 & $1(0)$ \\
\hline FDR & 7,5441 & 0,0000 & $1(0)$ \\
\hline SBIS & 4,1309 & 0,0031 & $1(0)$ \\
\hline SBPUS & 6,1492 & 0,0000 & $1(0)$ \\
\hline
\end{tabular}

Source: Results Processed by the Researchers (2017)

From the results of unit root test on table 2 above it can be determined that the data on each variable is stationary on the first difference which can be seen from the ADF value (P-Value) less than 0.05.

\section{b. Determining the Lag Optimum}

Determining the lag optimum is used to decide how much lag criteria will be used in advanced VAR testing such as on Impulse Response Function dan Variance decomposition. The criteria of lag optimism can be seen from the criteria indicated by many tests such as LR, FPE, AIC, SC, and HQ.

Table 3. Results of Lag Optimum CriteriaTest

VAR Lag Order Selection Criteria

Endogenous variables: CAR FDR ROA SBIS SBPUS

Exogenous variables: C

Date: 12/04/17 Time: 14:13

Sample: 133

Included observations: 29

\begin{tabular}{ccccccc}
\hline \hline Lag & LogL & LR & FPE & AIC & SC & HQ \\
\hline \hline 0 & -606.7189 & NA & $1.44 \mathrm{e}+12$ & 42.18751 & 42.42325 & 42.26134 \\
1 & -516.6669 & 142.8412 & $1.68 \mathrm{e}+10$ & 37.70116 & 39.11561 & 38.14415 \\
2 & -486.3605 & 37.62167 & $1.38 \mathrm{e}+10$ & 37.33521 & 39.92836 & 38.14735 \\
3 & -442.3405 & $39.46622^{*}$ & $6.06 \mathrm{e}+09$ & 36.02348 & 39.79534 & 37.20478 \\
4 & -389.8686 & 28.95002 & $3.12 \mathrm{e}+09^{*}$ & $34.12887^{*}$ & $39.07942^{*}$ & $35.67932^{*}$ \\
\hline \hline
\end{tabular}

* indicates lag order selected by the criterion

LR: sequential modified LR test statistic (each test at $5 \%$ level)

FPE: Final prediction error

AIC: Akaike information criterion

SC: Schwarz information criterion

$H Q$ : Hannan-Quinn information criterion

Source: Results Processed by the Researchers (2017) 
From the result of the lag optimum test on table 3 above it can be determined that the lag optimum on this model is already on 4. It can be seen from the result indicated by FPE, AIC, SC, and HQ (mark*).

\section{c. Impuls Respone Function (IRF)}

IRF functions to see the response of other variables when impulses happen, or in other words innovation or error terms (e), in a variable. In this study, it can be seen the response from CAR, FDR, and ROA variable (which is a response) when there is a shock on sharia monetary instrument (SBIS and SBPUS). It is expected that the response is different for each sharia monetary instrument.

Graphic 1. Impuls Respone Function (IRF) of Sharia Monetary Instrument
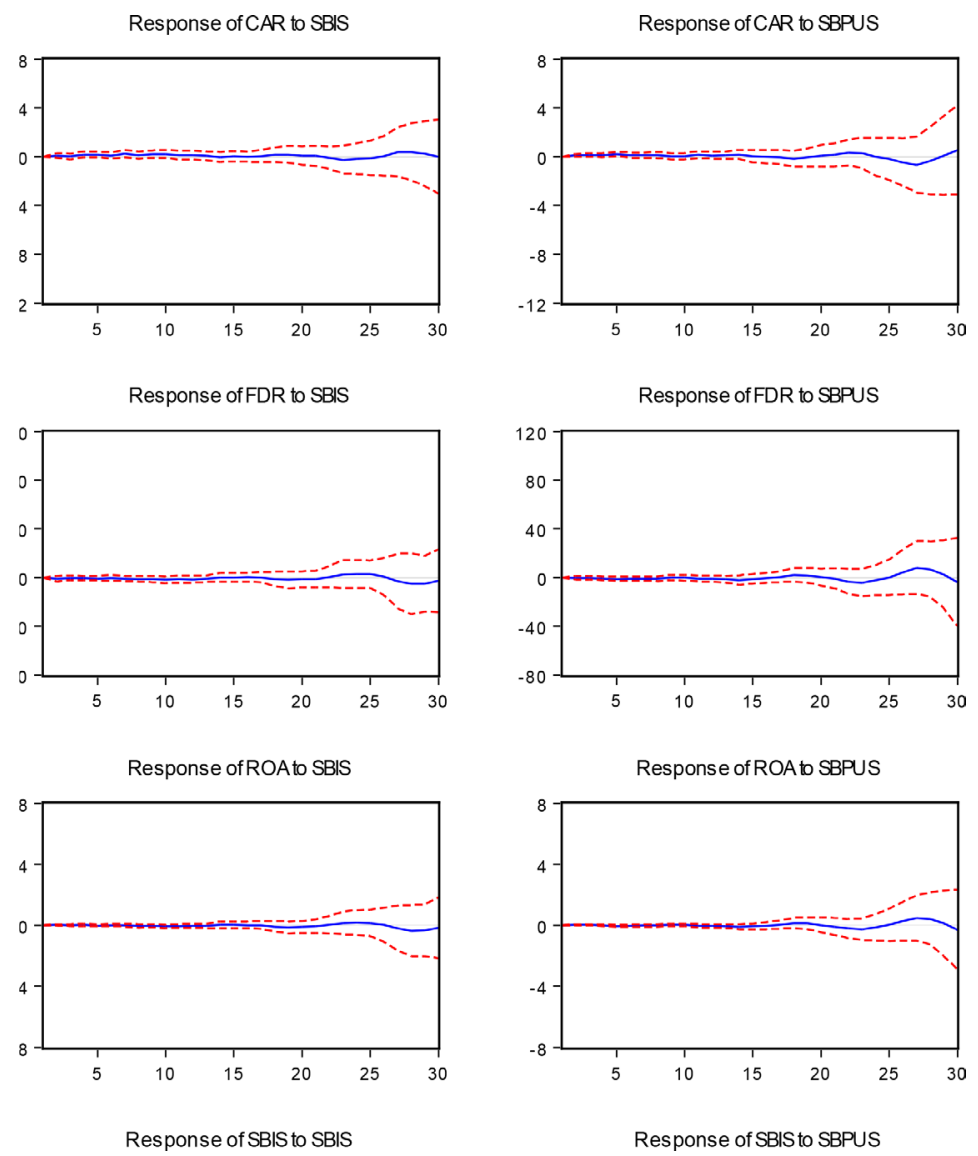


\section{d. Variances Decomposition}

It can be used to see how much a variable shock contributes to other variables and how long the shock proportion lasts. Below is the conclusion of result from variance decomposition in this study:

Table 3. Variance Decomposition Result

\begin{tabular}{ccc}
\hline Variabel & SBIS & SBPUS \\
\hline CAR & $48,15 \%$ & $44,57 \%$ \\
FDR & $33,49 \%$ & $36,85 \%$ \\
ROA & $7,6 \%$ & $5,7 \%$ \\
\hline
\end{tabular}

Source: Results Processed by the Researchers (2017)

\section{Research Result Interpretations}

This research analyzed and determined the variables exists in liquidity management and financial performance of sharia banking that contributes in the change of transaction volume in sharia monetary instrument as well as determined which of the instrument is better to serve sharia banking in liquidity management and financial performance of sharia banking in Indonesia. Based on the previous research, banks who experienced excess liquidity will do the liquidity transform in a form of monetary instrument. ${ }^{46}$ For sharia banking case in Indonesia, this liquidity transformation is directed to the sharia SBI issued by Central Bank encouraged as a means to minimalized risks factor. ${ }^{47}$ This shows that excess liquidity of sharia banking in Indonesia tends to be directed towards utilization of liquidity instrument available on central bank such as SBIS or in the money market as SBPUS. The choice of instrument to absorb liquidity is also determined by risk factor and expected return. Therefore, deciding on the sharia monetary instrument is still performed by considering the better financial performance for the sharia banking in Indonesia.

\footnotetext{
${ }^{46}$ Akash Deep and Guido K. Schaefer, 'Are Banks Liquidity Transformers?', p. 1-53.

47 Irsadunas Irsadunas, 'Analisis Terhadap Faktor-Faktor Yang Mempengaruhi Posisi Outstanding SWBI.', p. 180-200.
} 
The result of this study also shows that based on the Variances Decomposition, the factors that give big contributions on sharia banking in using the monetary instrument in bank central and money market are CAR dan FDR. In addition, based on Impuls Respons Function, SBIS monetary instrument during the research period is better to be used by sharia banking in Indonesia instead of SBPUS. From this result, it can be concluded that the biggest contributing factor in the placement of excess liquidity is dominated by liquidity variables (CAR and FDR) rather than return variable (ROA). SBIS is better than SBPUS to be used in sharia banking in Indonesia to put its excess liquidity. It can be understood that sharia banking tends to find the relatively safe monetary instrument or non-risky ones rather than pursuing a return to put their excess liquidity. It can be explained that in choosing a monetary instrument, sharia banking is more influenced by the risk factor rather than the return factor.

\section{Conclusion}

Based on the result of this study it can be concluded that CAR and FDR variables are those who mainly contribute to the change of transaction volume in sharia monetary instrument performed by sharia banking. In addition, SBIS instrument has the better effect on sharia banking performance in Indonesia compared to the SBPUS. Based on this finding it can also be concluded that sharia banking in Indonesia is likely to consider risk issue in liquidity management rather than return issue.

Furthermore, the researcher suggests sharia banking in Indonesia to place their excess liquidity on SBIS instrument, which is relatively safe compared to the other instruments. In addition to SBIS placement being safer than others, it can also get competitive return rate compared to others. Therefore, if sharia banking uses SBIS as the choice of liquidity management, it can get two characteristics of a good business, which is safe from the risk point of view but still receive the good return from the return point of view. Moreover, in order to decrease fund placement of sharia banking in the monetary instrument other than core business of the banking, it should decrease the CAR ratio and improve FDR 
ratio to minimalized the idle fund that will bring liquidity problems in the future.

\section{Bibliography}

Abdullah, D.V. Liquidity Management in Institutions Offering Islamic Financial Services. Paper Presented at The Second Islamic Financial Stability Forum, Jeddah, Kingdom of Saudi Arabia, 2010.

Adam, M.H.M. Evaluating The Financial Performance Of Banks Using Financial Ratios-Acase Study Of Erbil Bank For Investment And Finance. European Journal of Accounting Auditing and Finance Research 2, no. 6, (2014): 156-170.

Adwan, R. N. S. Risk Management In Islamic Banking. International Review of Management and Business Research 3, no. 4, (2014): 18551861.

Afiatun, P. \& Wiryono, S.K. Efficiency and Productivity of Indonesian Islamic Banking. Jurnal Manajemen Teknologi 9, no. 3, (2010): 264278.

Aggarwal \& Yousef. Islamic Banks and Investment Financing. Journal of Money, Credit and Banking 32, no. 1, (2000): 93-120.

Al-Sayed. O. Money Market Instruments in Conventional and Islamic Banks. European International Journal of Science and Humanities 1, no. 3, (2015): 1-9.

Alshatti. The Effect of the Liquidity Management on Profitability in The Jordanian Commercial Banks. International Journal of Business and Management 10, no. 1, (2015): 62-71.

Andriansyah, Y. Kinerja Keuangan Perbankan Islam di Indonesia dan Kontribusinya bagi Pembangunan Nasional. Jurnal Ekonomi Islam La_Riba 3, no. 2, (2009): 181-196.

Anwar, D. Dampak Transaksi Instrumen Moneter Syariah terhadap Kinerja Perbankan Syariah di Indonesia. (Master Thesis), Universitas Indonesia, Jakarta, 2007.

Archer, S., Karim, R.A.A., \& Sundarajan, V. Supervisory, Regulatory, and Capital Adequacy Implications of Profit-Sharing Investment 
Accounts in Islamic Fnance. Journal of Islamic Accounting and Business Research 1, no. 1, (2010): 11-12.

Ariffin, N. M. Liquidity Risk Management And Financial Performance In Malaysia: Empirical Evidence From Islamic Banks. Aceh International Journal of Social Sciences 1, no. 2, (2012): 77-84.

Beck, T., Levine, R., \& Loayza, N. Finance and the Sources of Growth. Journal of Financial Economics, 58, no. 1-2, (2000): 261-300.

Chapra, U. Sistem Moneter Islam. Jakarta: Gema Insani Press, 2000.

Chou. T., \& Buchdadi. A.D. Bank Performance and Its Underlying Factors: A Study of Rural Banks in Indonesia. Accounting and Finance Research 5, no. 3, (2016): 55-63.

Deep. A. \& Schaefer, G.K. Are Banks Liquidity Transformers? KSG Working Paper No. RWP04-022. (2004). Available at SSRN: http:// ssrn.com/abstract $=556289$.

Diamond, D.W. Liquidity, Banks, and Markets: Effects of Financial Development on Banks and the Maturity of Financial Claims. World Bank Policy Research Working Paper No. 1566. (1996). Retrieved from SSRN: http://ssrn.com/abstract=615033.

Furqani, H. \& Mulyany, R. Islamic Banking and Economic Growth: Empirical Evidence from Malaysia. Journal of Economic Cooperation and Development 30, no. 2, (2009): 59-74.

Ichsan, N. Pengelolaan Likuiditas Bank Syariah. Jurnal Al-Iqtishad 6, no. 1, (2014): 82-103.

Irsadunas. Analisis Terhadap Faktor-Faktor yang Mempengaruhi Posisi Outstanding SWBI. (Master Thesis) Universitas Indonesia, Jakarta, 2004.

Ismal, R. The Management Of Liquidity Risk In Islamic Banks: The Case Of Indonesia, Durham theses, Durham University. (2010). Available at Durham E-Theses Online: http://etheses.dur.ac.uk/550/.

Ismal, R. Central Bank Islamic Monetary Instruments: A Theoretical Approach. Studies in Economics and Finance 28, no. 1, (2011): 51-67.

Kasri, R.A. The Determinants of Islamic Banking Growth in Indonesia. Journal of Islamic Economics, Banking and Finance 3, no. 2, (2010): 41-64. 
Khan, T. \& Ahmed, H. Risk Management: An Analysis of Issues in Islamic Financial Industry. Occasional Papers, Jeddah: The Islamic Research and Teaching Institute (IRTI), 2001.

Kurniasih, Asih. Pengaruh Pembiayaan dan Transaksi Pasar Uang Antar Bank Syariah Terhadap Sertifikat Wadiah Bank Indonesia Tahun 20002004, (Master Thesis) Universitas Indonesia, Jakarta, 2005.

Laksono. B.G. Model Vector Auto Regressive, (Modul Kuliah) Universitas Indonesia, Jakarta, 2006.

Lartey, V.A \& Boadi, E. The relationship between liquidity and profitability of listed banks in Ghana. International Journal of Business and Social Science, 4, no. 3, (2013): 48-56.

Leon, B.\& Ericson, S. Manajemen Aktiva Pasiva Bank Non Devisa. Jakarta: PT. Grasindo, 2007.

Lori. G., Jafarey. S., \& Padilla., F. Systemic Risk on The Interbank Market. London: Kings College Strand, 2004.

Muhammad. Lembaga-lembaga Keuangan Umat Kontemporer. Yogyakarta: UII Press, 2000.

Otoritas Jasa Keuangan. Transparansi dan Publikasi Laporan Bank Umum Islam dan Unit Usaha Islam (Lampiran Pedoman Surat Edaran Nomor 18/SEOJK.03/2015), Jakarta, 2015.

Pramuharjo, A. B. Analisis Pengaruh Kebijakan Moneter terhadap Deposito, Pembiayaan, dan Likuiditas Perbankan Syariah di Indonesia, (Master Thesis), Univeritas Indonesia, Jakarta, 2005.

Ramzan, M., \& Zafar, I. Liquidity Risk Management in Islamic Banks: A Study of Islamic Banks of Pakistan. Interdisciplinary Journal of Contemporary Research in Business, 5, no. 12, (2014): 199-215.

Ruliana. T., Hariyadi. R.M. \& Winarsih. S. Health Level Of Bank Using Risk Based Bank Rating. Scientific Papers Series Management, Economic Engineering in Agriculture and Rural Development 16, no. 1, (2016): 451-458.

Sandy, G.E. Pengaruh Liquiditas Dan Solvabilitas Terhadap Kinerja Keuangan Perbankan Indonesia Yang Terdaftar di Bursa Efek Indonesia Pada Tahun 2010 - 2012, Universitas Jember, Jember, 2015. 
Sarker, A.A. An Evaluation of Islamic Monetary Policy Instruments Introduced in Some Selected OIC Member Countries. Islamic Economics Studies 24, no. 1, (2016): 1-47.

Siregar, M. Agenda Pengembangan Perbankan Islam Untuk Mendukung Sistem Ekonomi yang Sehat di Indonesia: Evaluasi, Prospek dan Arah Kebijakan. Iqtisad: Jurnal Ekonomi Islam 3, no. 1, (2002): 46-66.

Sulaiman, A.A., Mohamad, M.T., \& Samsudin, M.L. How Islamic Banks of Malaysia Managing Liquidity? An Emphasis on Confronting Economic Cycles. International Journal of Business and Social Science 4, no. 7, (2013): 253-263.

Syukron, A. Dinamika Perkembangan Perbankan Islam di Indonesia. Economic: Jurnal Ekonomi dan Hukum Islam 3, no. 2, (2013): 28-35.

Tanuwidjaja, E. \& Choy., K.M. Central Bank Credibility and Monetray Policy in Indonesia, Journal of Policy Modelling 28, (2006): 10111012.

Thantawi, T.R. Pengaruh Kebijakan Bonus SWBI dan Penjaminan Pemerintah Terhadap Tingkat Imbalan Pasar Uang Antar Bank Berdasarakan Prinsip Syariah di Indonesia. (Master Thesis) Univeristas Indonesia, Jakarta, 2005.

Utama, C. Mengukur Tingkat Kesehatan Bank di Indonesia. Jurnal Bina Ekonomi, 10, no. 1, (2006): 48-56.

Wagner, W. The Liquidity of Bank Assets and Banking Stability. (2004). Retieved from SSRN: http://ssrn.com/abstract=556128 or http:// dx.doi.org/10.2139/ssrn.556128

Widagdo., Kuncara, A., Ika. \& Rochmah S. The Interest Prohibition and Financial Performance of Islamic Banks: Indonesian Evidence. International Business Research 1, no. 3, (2008): 98-109.

Wuryandani. G., Ginting. R., Iskandar. D., \& Sitompul. Z. Perilaku Bank Dalam Penghimpunan dan Penempatan Dana: Implikasi Terhadap Likuiditas. Buletin Ekonomi Moneter dan Perbankan. Bank Indonesia, 2012. 